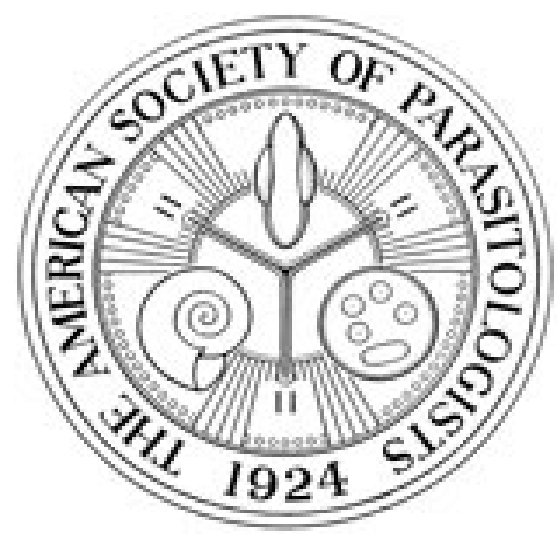

Characterization of Temperature-Sensitive Strains of Neospora caninum in Mice Author(s): David S. Lindsay, Steve D. Lenz, Byron L. Blagburn and David A. Brake Source: The Journal of Parasitology, Vol. 85, No. 1 (Feb., 1999), pp. 64-67

Published by: The American Society of Parasitologists

Stable URL: http://www.jstor.org/stable/3285701

Accessed: 19/06/2014 10:31

Your use of the JSTOR archive indicates your acceptance of the Terms \& Conditions of Use, available at http://www.jstor.org/page/info/about/policies/terms.jsp

JSTOR is a not-for-profit service that helps scholars, researchers, and students discover, use, and build upon a wide range of content in a trusted digital archive. We use information technology and tools to increase productivity and facilitate new forms of scholarship. For more information about JSTOR, please contact support@jstor.org.

The American Society of Parasitologists is collaborating with JSTOR to digitize, preserve and extend access to The Journal of Parasitology. 


\title{
CHARACTERIZATION OF TEMPERATURE-SENSITIVE STRAINS OF NEOSPORA CANINUM IN MICE
}

\author{
David S. Lindsay, Steve D. Lenz, Byron L. Blagburn*, and David A. Brake† \\ Center for Molecular Medicine and Infectious Diseases, Department of Biomedical Sciences and Pathobiology, Virginia-Maryland Regional \\ College of Veterinary Medicine, Virginia Tech, 1410 Prices Fork Road, Blacksburg, Virginia 24061-0442
}

\begin{abstract}
Temperature-sensitive (ts) strains of the Neospora caninum tachyzoites were selected by chemical mutagenesis and selection for growth at $32 \mathrm{C}$. Three ts strains and the parental, $N$. caninum wild-type strain, NC-1, were examined in the present study for their ability to cause disease in inbred BALB/c mice, outbred ICR mice, and chemically immunosuppressed ICR mice. In BALB/c mice, all 3 strains failed to induce clinical disease, whereas infection with the NC-1 strain caused central nervous system disease and death in some mice. No disease was observed in ICR mice inoculated with the 3 ts strains or the NC-1 strain. All immunosuppressed ICR mice inoculated with the NC-1 strain died, whereas no immunosuppressed mice inoculated with the NCts-4 strain and only 1 of 5 mice inoculated with the NCts-8 and NCts- 12 strains died. The NCts- 4 and NCts- 12 strains reverted to a wild-type phenotype when grown at $37 \mathrm{C}$. Vaccination of BALB/c mice with live, but not frozen NCts- 8 strain tachyzoites induced significant $(P<0.05)$ protection following NC-1 strain challenge.
\end{abstract}

Neospora caninum is a major cause of abortion in dairy cattle worldwide (see Dubey and Lindsay, 1996). Cattle that abort do not become immune and can reabort during several consecutive pregnancies. Little is known about the immune response to $N$. caninum in cattle, and no vaccines are available against $N$. caninum in any animal species.

Modified live vaccines have been developed for the vaccination of animals against Toxoplasma gondii, a protozoan structurally and biologically related to $N$. caninum. The temperaturesensitive (ts) mutant ts-4 (Pfefferkorn and Pfefferkorn, 1976) has been demonstrated to be safe and afford protection in several mammalian hosts, including mice, hamsters, monkeys, and pigs (Waldeland and Frenkel, 1983; Waldeland et al., 1983; Elwell and Frenkel, 1984a, 1984b; Escajadillo and Frenkel, 1991; Lindsay et al., 1993; Pinckney et al., 1994, 1995). The S48 mutant has been evaluated against abortion in sheep and is safe and effective (O'Connel et al., 1988; Buxton et al., 1991; Buxton and Innes, 1995; Wastling et al., 1994, 1995). The objective of the present study was to develop and characterize ts strains of $N$. caninum and to evaluate their safety and efficacy in an $N$. caninum encephalitic mouse model (Lindsay et al., 1995; Long et al., 1998).

\section{MATERIALS AND METHODS}

\section{Generation of cloned parasite strains}

The NC-1-2C line (Lindsay et al., 1996) of the NC-1 strain of $N$. caninum was used to generate ts mutants. This line was exposed to 0.5 $\mu$ mol $N$-methyl- $N$-nitro- $N$-nitrosoquanidine for $24 \mathrm{hr}$. It was then grown at $32.5 \mathrm{C}$ for $3 \mathrm{mo}$ after which it was cloned by limiting dilution. Twelve clones were isolated and 3 selected for further study. The NCts-4, NCts8 , and NCts- 12 clones had been maintained at $32.5 \mathrm{C}$ for $>8$ mo before use in the present studies. These strains were examined for reversion to wild-type phenotype by continuous propagation at $37 \mathrm{C}$ for 88 days $(25$ cell culture passes) prior to use (NCts-4-37, NCts-8-37, NCts-12-37) in experiment 3.

\section{Mice}

Mice used were outbred ICR and inbred BALB/c strains obtained from the same commercial supplier (Harlan Sprague Dawley, Indianap-

Received 29 June 1998; revised 16 September 1998; accepted 16 September 1998.

* Department of Pathobiology, College of Veterinary Medicine, Auburn University, Alabama 36849

$\dagger$ Animal Health Biological Discovery, Pfizer Central Research, Eastern Point Road, Groton, Connecticut 06340 olis, Indiana). Mice were 18-22-g females, housed in groups of 4 or 5 in plastic box cages, and provided rodent chow and water ad libitum.

\section{Serological testing}

The indirect immunofluorescent antibody (IFA) test was used to examine sera for antibodies to $N$. caninum from mice (Cole et al., 1995). Sera were obtained from mice immediately prior to challenge inoculation in vaccination studies (experiment 4 ) and obtained from all mice that survived pathogenicity experiments. Sera were examined for IgG $N$. caninum-specific antibodies at doubling dilutions beginning at 1:50 and end-point titrated. Air-dried tachyzoites were used as antigen. Positive samples exhibited a complete tachyzoite surface fluorescence. Negative samples exhibited no fluorescence or only anterior end fluorescence.

\section{Cell culture assay for identification for $\boldsymbol{N}$. caninum tissue cysts in mouse brain}

The brain from each mouse was removed at necropsy, and half was fixed in 10\% neutral buffered formalin solution and used for histopathologic examination (see lesion scores below). The remaining half was used for acid-pepsin digestion and inoculation of cell cultures to detect tissue cysts of $N$. caninum. The portion of brain was placed in $3 \mathrm{ml}$ of Hanks' balanced salt solution (HBSS) and passed through a syringe. This homogenate was then passed 2 times through a syringe equipped with a 23-gauge needle. Three milliliters of acid-pepsin solution $(0.52$ $\mathrm{g}$ of pepsin, $0.50 \mathrm{~g}$ of $\mathrm{NaCl}, 98.6 \mathrm{ml}$ of distilled water, and $1.4 \mathrm{ml}$ of concentrated $\mathrm{HCl}$ ) was added to the homogenate, and it was incubated for $10 \mathrm{~min}$ at $37 \mathrm{C}$ in a water bath. The acid pepsin solution was then removed by centrifugation, and the entire contents (half brain) was inoculated onto a $25 \mathrm{~cm}^{2}$ tissue culture flask containing HS68 cells. The inoculated material was removed $30 \mathrm{~min}$ later, and HS68 cell monolayer was washed with media and incubated in maintenance medium. The flasks were maintained for 28 days after which they were considered negative if no stages of $N$. caninum were isolated.

\section{Microscopic lesion scores}

The following criteria were used for histologic lesion scoring (Lindsay et al., 1995). Number of inflammatory or necrotic foci: no foci $=$ $1 ; 1-5$ foci $=2 ; 6-10$ foci $=3 ;>10$ foci $=4$. Average size of foci: none $=1 ; 100-200 \mu \mathrm{m}=2 ; 200-500 \mu \mathrm{m}=3 ;>500 \mu \mathrm{m}=4$. Severity of lesions: no lesions $=1$; slight $=2 ;$ mild $=3$; moderate $=4$; marked $=5$. A mean lesion score was obtained from these 3 values. A normal noninfected mouse brain would have a mean lesion score of 3.0. Mean lesion scores were evaluated using a Kruskal-Wallis nonparameteric test and distribution free multiple comparisons methods (Zar, 1984). The numbers of mice in each group with lesions was examined using Fisher's exact test. Significance was established at a cutoff of $P<0.05$ prior to conduct of analysis of data. 
TABLE I. Protocol and clinical outcome of BALB/c mice inoculated subcutaneously with Hanks' balanced salt solution (HBSS) or 500,000 tachyzoites of NC-1, NCts-4, NCts-8, or NCts-12 strains of Neospora caninum.

\begin{tabular}{|c|c|c|c|}
\hline Group & $\begin{array}{l}\text { No. of } \\
\text { mice }\end{array}$ & Strain & Clinical outcome \\
\hline 1 & 4 & HBSS & Two mice killed 42 and 56 days. \\
\hline 2 & 5 & NCts-4 & All mice killed 42 days PI. No mortality. \\
\hline 3 & 5 & NCts-4 & All mice killed 56 days PI. No mortality. \\
\hline 4 & 5 & NCts-8 & All mice killed 42 days PI. No mortality. \\
\hline 5 & 5 & NCts-8 & All mice killed 56 days PI. No mortality. \\
\hline 6 & 5 & NCts-12 & All mice killed 42 days PI. No mortality. \\
\hline 7 & 5 & NCts-12 & All mice killed 56 days PI. No mortality. \\
\hline 8 & 5 & NC-1 & $\begin{array}{l}\text { Mice developed clinical neosporosis at } \\
\text { around } 16 \text { days PI. They were less ac- } \\
\text { tive than groups } 1-7 \text { and had rough hair } \\
\text { coats. Two mice were killed because of } \\
\text { neosporosis } 34 \text { days PI, and an addition- } \\
\text { al mouse died } 39 \text { days PI. The remain- } \\
\text { ing } 2 \text { mice were killed } 56 \text { days PI. }\end{array}$ \\
\hline 9 & 5 & NC-1 & $\begin{array}{l}\text { Clinical signs same as group } 8 \text {. Mice were } \\
\text { found dead on days } 26,30,32 \text {, and } 41 \\
\text { after inoculation. The remaining mouse } \\
\text { was killed } 56 \text { days PI. }\end{array}$ \\
\hline
\end{tabular}

\section{Experiment 1: Pathogenicity of NC-1 and NCts strains of $N$. caninum in BALB/c mice}

Forty-four BALB/c mice were used in experiment 1 . Mice were inoculated subcutaneously (s.c.) with HBSS or 500,000 tachyzoites of the NC-1, NCts-4, NCts-8, or NCts-12 strains of $N$. caninum, and all surviving mice were killed and examined at necropsy 42 or 56 days postinoculation (PI) (Table I). Serum was collected from surviving mice at necropsy. Brains were obtained and used for microscopic lesions scores and parasite isolation.

\section{Experiment 2: Pathogenicity of NC-1 and NCts strains of $\mathbf{N}$. caninum in ICR mice}

Twenty-five ICR mice were used in experiment 2. Mice were inoculated s.c. with HBSS or 500,000 tachyzoites of the NC-1, NCts-4, NCts-8, or NCts-12 strains of $N$. caninum. All surviving mice were killed 56 days PI. Sera were collected for IFA testing. Brains were collected for microscopic lesions scores and parasite isolation.

\section{Experiment 3: Pathogenicity of NC-1, NCts strains, and NCts revertant strains of $\boldsymbol{N}$. caninum in immunosuppressed ICR mice}

Forty ICR mice were used in experiment 3 . All mice were immunosuppressed by intramuscular administration of $2 \mathrm{mg}$ of methylprednisolone acetate on days 7, 0, and 7 PI (Lindsay and Dubey, 1989). Mice were inoculated s.c. with HBSS or 200,000 tachyzoites of NC-1, NCts-4, NCts-8, and NCts-12 strains or reversion controls NCts-4-37, NCts-8-37, and NCts-12-37 on day 0. Surviving mice were killed and examined at necropsy 56 days PI. Sera were collected for IFA testing. Brains were collected for microscopic lesions scores and parasite isolation.

\section{Experiment 4: Vaccination of BALB/c mice against $\boldsymbol{N}$. caninum induced encephalitis}

Thirty-five BALB/c mice were used in experiment 4 . Mice were vaccinated s.c. with HBSS, 500,000 freshly isolated tachyzoites of the NCts-8 strain, or $2 \times 10^{6}$ killed (frozen) tachyzoites by s.c. inoculation (Table VI ). Mice were boosted 21 days PI with identical preparations of HBSS or parasites. Mice were challenged s.c. with $1 \times 10^{6} \mathrm{NC}-1$ strain tachyzoites or HBSS 14 days after the second vaccination. Surviving mice were killed and examined at necropsy 56 days PI. Sera were collected for IFA testing. Brains were collected for microscopic
TABLE II. Mean lesion scores of BALB/c mice inoculated subcutaneously with Hanks' balanced salt solution (HBSS) or 500,000 tachyzoites of NC-1, NCts-4, NCts-8, or NCts-12 strains of Neospora caninum in experiment 1 .

\begin{tabular}{llc}
\hline & $\begin{array}{c}\text { No. of mice with } \\
\text { lesions/no. } \\
\text { examined/no. } \\
\text { survived* }\end{array}$ & $\begin{array}{c}\text { Mean lesion } \\
\text { score }\end{array}$ \\
\hline Group 1 treatment & $0 / 4 / 4$ & 3.00 \\
Groups 2 + 3/NCts-4 & $4 / 10 / 10^{*}$ & 4.80 \\
Groups 4 + 5/NCts-8 & $6 / 10 / 10^{*}$ & 5.50 \\
Groups 6 + 7/NCts-12 & $5 / 10 / 10^{*}$ & 4.90 \\
Groups 8 $+9 / \mathrm{NC}-1$ & $8 / 8 / 3^{*} \dagger$ & $9.38^{*} \dagger$ \\
\hline
\end{tabular}

* Significantly different from controls (HBSS) $(P<0.05)$.

$\dagger$ Significantly different from NCts4, NCts-8, and NCts-12 $(P<0.05)$.

lesions scores and parasite isolation. The viability of the frozen vaccine was examined by inoculation of HS68 cell cultures immediately following primary and secondary immunizations.

\section{RESULTS}

\section{Experiment 1}

Clinical neosporosis and mortalities occurred only in BALB/ c mice infected with the NC-1 strain (Table I). Three of 10 BALB/c mice challenged with NC-1 survived through the 8wk study period. None of the sham-infected or NCts-mutantinfected BALB/c mice died, and significant differences in mean lesion scores between NCts-mutant groups and the NC-1-infected group were found (Table II). No tissue cysts were observed in histological sections of mouse brain, and no parasites were reisolated from cell culture from any group.

No antibodies to $N$. caninum were detected in sham-infected mice examined 42 days PI, or 56 days PI. Mice inoculated with the NCts-4 strain had $N$. caninum antibody titers ranging from $1: 800$ ( 1 mouse) to $1: 1,600$ ( 4 mice) 42 days PI, and all mice had a 1:1,600 titer 56 days PI. Mice inoculated with the NCts8 strain showed antibody titers ranging from 1:1,600 (3 mice) to $1: 3,200$ ( 2 mice) at both 42 and 56 days PI. Similar antibody titers from NCts-12 strain inoculated mice were also detected. Mice inoculated with the NC-1 strain and examined 56 days PI had titers of $1: 1,600$ (3 mice).

\section{Experiment 2}

None of the parasite strains caused mortality in ICR mice, and no significant differences were observed in numbers of mice with lesions or in the mean lesions scores (Table III). No tissue cysts were observed in histological sections of mouse brain, and parasites were not isolated from brain tissue inoculated cell cultures.

No antibodies to $N$. caninum were detected in 5 control mice examined 56 days PI. Mice inoculated with the NCts-4 strain and examined 56 days PI had titers ranging from 1:400 (1 mouse), to $1: 800$ ( 3 mice), with a fifth mouse at $1: 1,600$. Mice inoculated with the NCts- 8 strain and examined 56 days PI had titers of 1:50 (1 mouse), 1:800 (2 mice), 1:1,600 (1 mouse), and 1:3,200 (1 mouse). Mice inoculated with the NCts-12 strain and examined 56 days PI had titers of 1:50 (1 mouse), 1:800 (3 mice), and 1:1,600 (1 mouse). Mice inoculated with the NC- 
TABLE III. Results of lesion scores of ICR mice inoculated subcutaneously with Hanks' balanced salt solution (HBSS) or 500,000 tachyzoites of NC-1, NCts-4, NCts-8, and NCts-12 strains of Neospora caninum in experiment 2 .

\begin{tabular}{lcc}
\hline & $\begin{array}{c}\text { No. of mice with } \\
\text { lesions/no. examined/ } \\
\text { no. survived }\end{array}$ & $\begin{array}{c}\text { Mean lesion } \\
\text { score* }\end{array}$ \\
\hline Group 10/HBSS & $0 / 5 / 5$ & 3.0 \\
Group 11/NC-1 & $3 / 5 / 5$ & 6.0 \\
Group 12/NCts-4 & $0 / 5 / 5$ & 3.0 \\
Group 13/NCts-8 & $1 / 5 / 5$ & 4.0 \\
Group 14/NCts-12 & $0 / 5 / 5$ & 3.0 \\
\hline
\end{tabular}

* No significant differences $(P>0.05)$ were present.

1 strain and examined 56 days PI had titers ranging from 1: 1,600 ( 2 mice) to $1: 3,200$ ( 3 mice) .

\section{Experiment 3}

The NC-1, NCts-4-37, and NCts-12-37 strains caused $100 \%$ mortality in immunosuppressed ICR mice (Table IV). The NCts-4, NCts-8, NCts-12, and NCts-8-37 strains were less pathogenic for immunosuppressed mice and caused $0-20 \%$ mortality. Microscopic lesion scores are presented in Table V. No tissue cysts were observed in histological sections of mouse brain, and parasites were not isolated from brain tissue-inoculated cell cultures.

All surviving mice were tested for antibody titers at 56 days PI. Mice inoculated with the NCts-4 strain had titers of $1: 100$ (1 mouse), 1:800 (1 mouse), 1:1,600 (1 mouse), 1:3,200 (1 mouse), and 1:6,400 (1 mouse). Mice inoculated with the NCts8 strain displayed titers of 1:1,600 (2 mice), 1:3,200 (1 mouse), and 1:6,400 (1 mouse). Mice inoculated with the NCts-12 strain possessed titers of 1:1,600 (1 mouse), 1:3,200 ( 2 mice), and 1: 6,400 (1 mouse). Finally, mice inoculated with the NCts-8-37 strain had titers of 1:3,200 (1 mouse), 1:6,400 ( 2 mice), and 1: 12,800 (1 mouse).

\section{Experiment 4}

None of the live, Ncts-8-immunized mice died prior to NC1 challenge. Mortality and mean lesion scores following challenge are shown in Table VI. Two of 8 sham-immunized (HBSS) mice and 3 of 10 mice inoculated with frozen NCts-8 tachyzoites died following NC-1 challenge. Neospora caninum tachyzoites were isolated in cell cultures inoculated with acid-
TABLE V. Results of lesion scores in immunosuppressed ICR mice inoculated subcutaneously with Hanks' balanced salt solution (HBSS) or 200,000 tachyzoites of NC-1, NCts-4, NCts-8, NCts-12, NCts-4-37, NCts-8-37, and NCts-12-37 strains of Neospora caninum in experiment 3.

\begin{tabular}{lcc}
\hline \multicolumn{3}{c}{ No. of mice with } \\
Group/treatment & $\begin{array}{c}\text { lesions/no. examined/ } \\
\text { no. survived }\end{array}$ & $\begin{array}{c}\text { Mean lesion } \\
\text { score }\end{array}$ \\
\hline Group 15/HBSS & $0 / 5 / 5$ & 3.0 \\
Group 16/NC-1 & $4 / 4 / 0^{*}$ & $9.8^{*}$ \\
Group 17/NCts-4 & $1 / 5 / 5$ & 3.6 \\
Group 18/NCts-8 & $2 / 5 / 4$ & 5.2 \\
Group 19/NCts-12 & $3 / 5 / 4$ & 6.2 \\
Group 20/NCts-4-37 & $3 / 3 / 0^{*}$ & 8.7 \\
Group 21/NCts-8-37 & $5 / 5 / 4^{*}$ & 8.2 \\
Group 22/NCts-12-37 & $4 / 4 / 0^{*}$ & $9.5^{*}$ \\
\hline
\end{tabular}

${ }^{a}$ Significantly different from controls (group 15 HBSS $)(P<0.05)$

pepsin digested brain tissue from 2 of 8 sham-immunized, challenged mice and 1 of 10 frozen NCts-8-immunized, challenged mice. In contrast, none of the mice immunized with live NCts8 tachyzoites died following NC-1 challenge, and attempts at parasite reisolation in cell culture were unsuccessful.

HBSS-immunized, challenged mice had antibody titers ranging from $1: 1,600(1 / 10)$ to $1: 6,400(3 / 10)$. Postboost, prechallenge titers in NCts-8-immunized mice ranged from 1:400 to $1: 6,400(9 / 20)$ with titers ranging from $1: 800$ to $1: 3,200$ by end of study. Postchallenge titers in NCts-8-immunized mice ranged from $1: 800(1 / 10)$ through $1: 1,600(8 / 10)$ to $1: 3,200$ Prechallenge titers in frozen NCts-8-immunized mice ranged from $<1: 50(6 / 10)$ to $1: 100(2 / 10)$. Following challenge the antibody titers of the surviving mice were 1:400 (1 mouse), 1 : 800 (1 mouse), 1:1,600 ( 2 mice),1:3,200 (2 mice), and 1:6,400 (1 mouse).

No parasites were isolated in cultures inoculated with frozen tachyzoites.

\section{DISCUSSION}

The present study demonstrates that the NCts-4, NCts- 8 , and NCts-12 strains are less pathogenic than the parental wild-type $\mathrm{NC}-1$ strain in BALB/c mice (experiment 1) and immunosuppressed ICR mice (experiment 3). Although lesions were present in brains of some mice inoculated with these ts strains, they were not statistically significant compared with controls (Tables I, V). A significant difference in lesion scores and numbers of

TABLE IV. Protocol and clinical outcome in immunosuppressed ICR mice inoculated subcutaneously with Hanks' balanced salt solution (HBSS) or 200,000 tachyzoites of NC-1, NCts-4, NCts-8, NCts-12, NCts-4-37, NCts-8-37, and NCts-12-37 strains of Neospora caninum in experiment 3.

\begin{tabular}{ccll}
\hline Group & No. of mice & \multicolumn{1}{c}{ Strain } & \multicolumn{1}{c}{ Clinical outcome } \\
\hline 15 & 5 & HBSS & All 5 mice survived 56 days. \\
16 & 5 & NC-1 & Mice were killed or died 20 days PI (3 mice), 22 days PI and 23 days PI. \\
17 & 5 & NCts-4 & All 5 mice survived 56 days. \\
18 & 5 & NCts-8 & One mouse killed 20 days PI. Four others survived 56 days. \\
19 & 5 & NCts-12 & One mouse died 22 days PI. Four others survived 56 days. \\
20 & 5 & NCts-8-37 & Mice died or were killed 13, 14 (2 mice), 16, and 21 days PI. \\
21 & 5 & NCts-12-37 & One mouse died 29 days PI. Four others survived 56 days. \\
22 & 5 & One mouse died and 4 were killed 14 days PI. \\
\hline
\end{tabular}


TABLE VI. Protocol and results of BALB/c mice vaccinated with Hanks' balanced salt solution (HBSS) or living or frozen NCts-8 strain tachyzoites and challenged with tachyzoites of the NC-1 strain of Neospora caninum in experiment 4.

\begin{tabular}{|c|c|c|c|c|c|}
\hline Group & $\begin{array}{c}\text { First } \\
\text { vaccination* }\end{array}$ & $\begin{array}{c}\text { Second } \\
\text { vaccination } \dagger\end{array}$ & Challenge $\ddagger$ & $\begin{array}{l}\text { No. of mice with } \\
\text { lesions/No. examined/ } \\
\text { No. survived }\end{array}$ & $\begin{array}{c}\text { Mean lesion } \\
\text { score }\end{array}$ \\
\hline 23 & HBSS & HBSS & NC-1 & $8 / 8 / 8$ & 9.3 \\
\hline 24 & NCts-8 & NCts-8 & HBSS & $1 / 10 / 10 \S$ & $3.4 \S$ \\
\hline 25 & NCts- 8 & NCts- 8 & NC-1 & $1 / 10 / 10 \S$ & $3.3 \S$ \\
\hline 26 & Frozen NCts- 8 & Frozen NCts- 8 & $\mathrm{NC}-1$ & $6 / 7 / 7$ & 7.7 \\
\hline
\end{tabular}

* First vaccination was subcutaneously (s.c.) with HBSS, with $5 \times 10^{5}$ living tachyzoites of the NCts- 8 strain or with $2 \times 10^{6}$ frozen tachyzoites of the NCts- 8 strain. $\dagger$ Second vaccination was s.c. 21 days PI with HBSS, with $5 \times 10^{5}$ living tachyzoites of the NCts-8 strain or with $2 \times 10^{6}$ frozen tachyzoites of the NCts-8 strain. $\$$ Challenge was s.c. 14 days after second vaccination with HBSS or $1 \times 10^{6}$ living tachyzoites of the NC-1 strain.

$\S$ Significantly different from HBSS-vaccinated group $23(P<0.05)$, and significantly different from frozen NCts-8-vaccinated group $26(P<0.05)$.

mice with lesions were found when the mice inoculated with the NC-1 strain were compared with mice inoculated with HBSS or NCts strains of $N$. caninum.

Two of the 3 ts strains (NCts-4-37 and NCts-12-37) were $100 \%$ lethal for immunosuppressed ICR mice after 25 continuous passages at $37 \mathrm{C}$ (Table $\mathrm{V}$ ). This suggests a reversion to a wild-type phenotype and were not further evaluated. In contrast, the NCts-8-37 strain caused mortality in only $20 \%$ of immunosuppressed mice examined, indicating a much lower incidence of reversion to virulence.

Experiment 4 demonstrated that vaccination of BALB/c mice with 2 doses of the NCts-8 strain provided significant protection against challenge with the NC-1 strain (Table VI). Mice immunized with live NCts-8 strain tachyzoites failed to develop clinical disease or die. Ncts-8-immunized, challenged mice had almost identical lesion scores as Ncts-8-immunized, nonchallenged mice, providing further evidence for protection using a live, experimental vaccine. However, immunization with nonviable, frozen NCTS-8 strain tachyzoites (experiment 4) offered little protection from neosporosis. This lack of protection with killed NCts- 8 tachyzoites is similar to what has been observed in sheep given killed $T$. gondii vaccines (Beverly et al., 1971; Wilkins et al., 1987; Buxton et al., 1989).

\section{LITERATURE CITED}

Beverly, J. K. A., J. F. Archer, W. A. Watson, and A. R. Fawcett. 1971. Trial of a killed vaccine in the prevention of ovine abortion due to toxoplasmosis. British Veterinary Journal 127: 529-535.

Buxton, D., AND E. A. InNES. 1995. A commercial vaccine for ovine toxoplasmosis. Parasitology 110: S11-S16.

-, A. Uggla, K. Lovgren, K. M. Thomson, A. Lunden, B. MorEIN, AND D. A. BLEWETT. 1989. Trial of a novel experimental Toxoplasma iscom vaccine in pregnant sheep. British Veterinary Journal 145: $451-457$.

-, D. K. Thomson, S. Maley, S. Wright, and H. J. Bos. 1991. Vaccination of sheep with a live incomplete strain (S48) of Toxoplasma gondii and their immunity to challenge when pregnant. Veterinary Record 129: 89-93.

Cole, R. A., D. S. Lindsay, B. L. Blagburn, and J. P. Dubey. 1995. Vertical transmission of Neospora caninum in mice. Journal of Parasitology 81: 730-732.

Dubey, J. P., AND D. S. LindSAy. 1996. A review of Neospora caninum and neosporosis. Veterinary Parasitology 67: 1-59.

Elwell, M. R., AND J. K. Frenkel. 1984a. Acute toxoplasmosis in hamsters and mice: Measurement of pathogenicity by fever and weight loss. American Journal of Veterinary Research 45: 26632667.

American Journal of Veterinary Research 45: $2668-2674$
Escajadillo, A., AND J. K. Frenkel. 1991. Experimental toxoplasmosis and vaccine test in Aotus monkeys. American Journal of Tropical Medicine and Hygiene 44: 382-389.

Lindsay, D. S., and J. P. Dubey. 1989. Neospora caninum (Protozoa: Apicomplexa) infections in mice. Journal of Parasitology 75: 772779.

, B. L. Blagburn, And J. P. Dubey. 1993. Safety and results of challenge of weaned pigs given a temperature-sensitive mutant of Toxoplasma gondii. Journal of Parasitology 79: 71-76.

$\longrightarrow$, S. D. Lenz, R. A. Cole, J. P. Dubey, and B. L. Blagburn. 1995. Mouse model for central nervous system Neospora caninum infections. Journal of Parasitology 81: 313-315.

-, J. M. Butler, N. S. Rippey and B. L. Blagburn. 1996. Demonstration of the synergistic effects of sulfonamides and dihydrofolate reductase/thymidylate synthase inhibitors against Neospora caninum tachyzoites in cultured cells, and characterization of mutants resistant to pyrimethamine. American Journal of Veterinary Research 57: 68-72.

Long, M. T., T. V. Baszler, and B. A. Mathison. 1998. Comparison of intracerebral parasite load, lesion development, and systemic cytokines in mouse strains infected with Neospora caninum. Journal of Parasitology 84: 316-320.

O'Connel, E., M. F. Wilkins, And W. A. TePunga. 1988. Toxoplasmosis in sheep: II. The ability of a live vaccine to prevent lamb losses after intravenous challenge with Toxoplasma gondii. New Zealand Veterinary Journal 16: 1-4.

PfEFFERKORN, E. R., AND L. C. PFEFFERKORN. 1976. Toxoplasma gondii: Isolation and preliminary characterization of temperature-sensitive mutants. Experimental Parasitology 39: 365-376.

Pinckney, R. D., D. S. Lindsay, B. L. Blagburn, T. R. Boosinger, S. A. McLaughlin, and J. P. Dubey. 1994. Evaluation of the safety and efficacy of vaccination of nursing pigs with living tachyzoites of two strains of Toxoplasma gondii. Journal of Parasitology 80: $438-448$.

, - AND 1995. Further characterization of the TS-4 temperature-sensitive mutant of Toxoplasma gondii in mice. Journal of Parasitology 81: 118-121.

Waldeland, H., AND J. K. FRENKEl. 1983. Live and killed vaccines against toxoplasmosis in mice. Journal of Parasitology 69: 60-65. , E. R. Pfefferkorn, And J. K. Frenkel. 1983. Temperaturesensitive mutants of Toxoplasma gondii: Pathogenicity and persistence in mice. Journal of Parasitology 69: 171-175.

Wastling, J. M., D. HARkins, AND D. Buxton. 1994. Western blot analysis of the IgG response of sheep vaccinated with S48 Toxoplasma gondii (Toxovax). Research in Veterinary Science 57: 384 386.

- S. Maley, E. Innes, W. Panton, K. Thomson, and D. Buxton. 1995. Kinetics of the local and systemic antibody response to primary and secondary infection with S48 Toxoplasma gondii in sheep. Journal of Comparative Pathology 112: 53-62.

Wilkins, M. F., E. O'Connell, And W. A. TePunga. 1987. Toxoplasmosis in sheep: I. Effect of a killed vaccine on lambing losses caused by experimental challenge with Toxoplasma gondii. New Zealand Veterinary Journal 35: 31-34.

ZAR, J. H. 1984. Biostatistical analysis, 2nd ed. Prentice Hall, Englewood Cliffs, New Jersey, 718 p. 